\title{
Po-Chia Tseng*
}

\section{Fear of Disconnecting: Global Health Imaginations and the Transformations of the Taiwanese State}

https://doi.org/10.1515/ngs-2020-0033

\begin{abstract}
Global health scholarship concerning AIDS governance often regards the global either as products of translocal connections or as external forces that initiate local restructurings. As a state without a membership in major global organizations, Taiwan alternatively presents a case for conceiving of global health as grounded, competing imaginations which serve as the foundation both for a symbolic pursuit of Taiwan's global membership and for the transformations of the Taiwanese state. Building on a global ethnography perspective, this study explores the idea of in-pursuit-of-globality nationalism by examining three AIDS projects in Taiwan that configured global and national imaginations simultaneously. It particularly looks into how sexuality and race became sites of transformative struggles in those projects, arguing that Taiwan's marginality is not only a product of global geopolitics but also a standpoint on which multiple globalities are imagined and (re)produced. As such, this study contributes to global health scholarship by rejecting a monolithic view of the global and the national and by centering racial and sexual imaginations in processes of globalization.
\end{abstract}

Keywords: globality, global health, global ethnography, transnational feminist sociology; Taiwan

\section{Introduction: Imagining Global Health from the Margins}

As the pandemic-inflicted situation has demonstrated, globalization has changed the ways in which people experience and respond to public health crises. This is especially true for the case of global health governance of AIDS in which transnational institutions, funds, and technologies have altered national and community responses to this pandemic. In the current scholarship on global AIDS

\footnotetext{
*Corresponding author: Po-Chia Tseng, University of Illinois at Urbana-Champaign, Urbana, 61801-3028, IL, USA, E-mail: ptseng6@illinois.edu
} 
governance, there are two main ways of conceptualizing global health. One body of scholarship considers the global as a powerful force from above that facilitates local changes. Some scholars taking this view have shown how states and their sovereignty were transformed as they engaged with transnational organizations and financial resources (Brown 2015; Harman 2009; Hartwig et al. 2005; Kaufman 2012; Long 2018; Powers 2016). Others have argued that transnational capital contributed to the mushrooming, remote governing, and reconfiguring of local nongovernmental organizations (Dehesa 2017; Gideon and Porter 2016; Jönsson and Jönsson 2012; Knutsson 2014; Swidler and Watkins 2017; Thörn 2016). Still others point to the reformation of identity and citizenship as globalizing scientific knowledge and biotechnologies travel across borders (Biehl 2007; Cassidy and Leach 2010; Decoteau 2013; Esacove 2016; Fassin 2007; Howard-Payne and Bowman 2018; Nguyen 2005; Persson 2016).

Another body of the scholarship views the global as a product of connections established and contested by translocal actors. For instance, studies have demonstrated how South African AIDS activism formed coalitions with transnational relief organizations to pressure the government and the global pharmaceutical industry to provide medicine (Robins 2004). Other studies show that in authoritarian contexts, domestic AIDS advocacy and activism has still been able to build connections with transnational funding without necessarily challenging or transforming the state (Chua and Hildebrandt 2014; Hood 2012). In the case of Brazil, various actors including the state, activists, the World Bank, and pharmaceutical multinationals jointly constructed a new market for the provision of AIDS drugs (Biehl 2004). Furthermore, there were south-south connections built between southern governments and NGOs that forged novel forms of AIDS governance (Follér 2010).

While these studies broaden our understanding of the complexity of global health governance, Taiwan presents an anomaly in the scholarship due to its status in international society and thereby offers a case to conceptualize global health from an alternative perspective. In 1971, the government representing Taiwan withdrew its membership in the United Nations and the World Health Organization, and the number of countries maintaining diplomatic relations with Taiwan has dropped significantly since then. Although the Taiwanese government has attempted to re-enter the UN in the 1990s and the WHO in the 2000s, these attempts have failed. As a result, Taiwan remained isolated from the global arena.

However, Taiwan's non-membership status in major international organizations does not preclude Taiwanese citizens and organizations from making reference to and building connections with the global. In this study I ask: How does Taiwan's isolated status in international society become a condition in which Taiwanese imagine global health and articulate global health norms and practices? To what extent does such a situated imagination of global health contribute to a 
transformation of the Taiwanese state? This study examines the ways in which Taiwan's health authority and AIDS advocates imagine global health, articulate nationhood, and facilitate changes in state practices, given the absence of Taiwan's connection with the UN, the WHO, and other global health agencies. It looks into and contrasts three distinct AIDS projects in Taiwan, assessing how scales beyond the national are constructed in these projects and how these constructions are implicated in shifting configurations of the Taiwanese state. In so doing, this study not only reveals what I call in-pursuit-of-globality nationalism - a nationalism asserted through a pursuit of a way of being part of the globe - in Taiwan, but also underscores the multiplicity of globalities engendered from below.

\section{Global Ethnography and Transnational Feminist Sociology}

A global ethnography contended by Burawoy and colleagues provides this study a methodological lens to explore the construction of scales beyond national border in situated imaginations. From the perspective of global ethnography, the making of a local place ought to be contextualized in the global processes and relations in which the local is embedded; moreover, the global should not be treated as an objectified, monolithic "thing” (Burawoy 2000; Gille and Riain 2002). One way, according to them, of countering the objectification of the global is to pay close attention to grounded vision of globalizations - what they call global imaginations. The framework of the global imagination is particularly useful for looking at the formation and transformation of Taiwan's AIDS governance, since members of Taiwan actively engaged in different projects that produced competing imaginations of global health which have implications for the local. As I will illustrate in this article, the transformation of the Taiwanese state and the corresponding shift in Taiwan's AIDS governance was a result of the politics of shifting global imaginations on the ground.

As this study focuses particularly on two dimensions - namely, sexuality and race - of the transformation of the state, it also draws on what Kim-Puri (2005, 143) elaborates as a transnational feminist sociology to analyze the changing racial and sexual configurations of the nation-state in a transnational context. In Kim-Puri's (2005) theorization, states and nations are being reconfigured in the face of various transnational processes such as colonialism, capitalism, and neoliberalism; more importantly, they argue that those transnational processes as well as states, nations, and nationalisms "are shaped through gendered, sexualized, and racialized imaginaries” (ibid, 143). These perspectives not only 
echo global ethnography on grounded views of globalization but are critical in scrutinizing the gendered, sexual, and racial nature of those views. In this study, I shall demonstrate how racialized, sexualized, and gendered imaginations of the global were invested in three projects responding to the emergent AIDS epidemic in Taiwan, and how these imaginations in turn facilitated transformative politics.

\section{Methods}

This study draws on archival research, discourse analysis, and in-depth interviews to trace the transformations of AIDS governance in Taiwan and to unpack the projects of global imagination that contributed to the transformations. I collected news archives and books on AIDS accessible to the general public in Taiwan since the 1980s, which represented earlier public discourses that served as a foundation for institutional responses to AIDS. I examined Taiwanese government archives including official and legislative gazettes, public health program documents, press briefings, health education manuals, and speeches. In addition, I collected varied sorts of texts issued by non-governmental organizations, including human rights reports, press briefings, publications, and newsletters. In analyzing these archives and texts, special attention is given to what and how things beyond national borders were imagined and enacted, as well as how sexual and racial citizenships were implicated in these projects.

During 2019, I conducted in-depth interviews with three officers from the Taiwan Centers for Disease Control, inquiring into policy-making processes and the role that actors outside Taiwan play in those processes. I also conducted interviews with four employees of Persons with HIV/AIDS Rights Advocacy Association, a key domestic nongovernmental organization (NGO) which worked on rights advocacy and legal protections for HIV-positive immigrants in Taiwan. The interviews focused on how they leveraged and gave meaning to actors and discourses outside Taiwan and how they engaged with Taiwan's legal regulation. The research procedure and ethics were preapproved by the Institutional Review Board at my affiliated institution.

\section{The Moral Project}

Since its global outbreak, AIDS had been constructed in Taiwan as a foreign disease and social problem encroaching the nation from the outside. When the first domestic HIV case was diagnosed in 1985 and was believed to have engaged in homosexual relations with foreign partners, the Ministry of Health made a national 
announcement about the case and "offered advice to homosexuals not to have sex with foreigners" (United News 1985). Although Taiwan was not provided with the information accessible to the member states of the WHO, the fact that the Taiwanese government, mass media, and public writers were closely following and reporting HIV case numbers from different parts of the world only increased and strengthened racialized and sexualized discourses of AIDS. In those discourses, the United States, Western Europe, Africa, and Southeast Asian countries gained the most public attention.

During the 1980s and 1990s, the metropolitan U.S. was depicted not only with astonishingly increasing HIV case numbers but also as a place rife with permissive sexuality. For instance, in a 1987 news report entitled "AIDS flourishes in New York," it was emphasized that more than two thousand people had died in New York City in the previous year and that there were already almost nine thousand HIV cases reported in the city (United News 1987a). In making sense of the severity of the epidemic, AIDS and Prevention Methods, a book for health education, states:

sexual liberation, sexual freedom, and the prevalence of homosexual behavior have made non-decent sexual relations common in the U.S., which constitute the ground for the transmission of sexually transmitted diseases and AIDS (Ho and Peng 1988, 16).

Similarly, another popular book Getting to Know about AIDS states:

In the 20th century, scientific development in Europe and America has brought about material richness more than ever, but it has also brought about loneliness in people's inner life, so people turn to sex ... there is even homosexuality and a social recognition of it, which adds to sexually transmitted diseases ( $\mathrm{Wu} 1990,11-12)$.

Such a sexual and racial construction of the U.S. and the West was consolidated as a number of these public discourses proliferated in Taiwan. The imagination of Western homosexuality became central in the imagination of AIDS in a global context.

As Western countries and Africa were presented both as the areas hardest hit by the pandemic and as the spreader of AIDS in the world, Asia was figured as a next target of AIDS's attack. A news article entitled “Asia will become a new battlefield as AIDS searches for a fall guy" warned, "Asia might become the next Africa” (United News 1987b). A few months later, another news article highlighted "Asia is in trouble as AIDS spreads" by citing the director of the World Health Organization (United News 1987c). However, racialized and sexualized discourses regarding the rising epidemic in Asia took a different form, mostly targeting transactional sex in Southeast Asian countries. In a news article entitled "Do not sleep around with wild flowers in the Philippines as AIDS is coming," it wrote, "according to statistics, there is one out of a thousand high-risk Philippine women 
infected by HIV ... it is believed that these high-risk women are those involved in prostitution" (United News 1987d).

Thailand was perhaps the Southeast Asian country mostly referenced in public discourses. For example, in What to Know about AIDS, a book published to educate the public, there was a chapter entitled "In Thailand, those infected [with AIDS] increases by a thousand times in five years, astonishing the world." In the chapter it was stated, "[i]n Asia, Thailand is the country where AIDS prevails the most ... it is likely because there are eight million women in prostitution, which create the conditions for a terrible crisis" (Yeh 1993, 229). Furthermore, in Global AIDS Prevention Manual, also a book for the general public, it was stressed that countries including Thailand, Myanmar, Malaysia, Indonesia, Vietnam, and India, were becoming the center of AIDS transmission in Asia because of sex consumption and drug use (Twu 1995, 57-59).

It was under such global imaginations of AIDS, supported by varied statistics, that the Taiwanese state articulated moral nationhood and citizenship, and configured itself into a defender of the moral nation against the global pandemic. Since 1987, the Ministry of Health had been distributing the AIDS Prevention Manual statewide, one issue of which stated:

Owing to the fear of AIDS, Western countries now have understood the importance of sexual norms.... We issue our serious call to every national to behave properly and comply with sexual norms. If [this call is heeded] ... AIDS could hardly be transmitted. Note that in the U.S., 73\% of AIDS patients were homosexuals (reprinted in Ko 1988, 2).

Likewise, "An open letter to the nation on the fight against AIDS," written and publicized by the Minister of Health in 1991, shared a similar narrative:

Today, a number of factors are contributing to the intensifying epidemic of AIDS in Taiwan: industrial and commercial developments, traveling, moral bankruptcy, pornography, migrant workers, and drug smuggling... If we are not alerted and fortified, the nation will be ravaged by AIDS just as it did Africa, the U.S., and Thailand (Min Sheng Daily 1991).

In these state narratives, it is clear that regions beyond national borders - the West, Africa, and Southeast Asia in particular - were invoked as a central element of racial, gendered, and sexual discourses which were produced to articulate a racially, sexually and gender-normative nationhood and to mobilize the state's apparatus against non-normativity. In other words, the nation was constructed in a moral framework, and the state geared up to fortify the nation against the threat by deviant racial, gender, and sexual subjectivities which were believed to be associated with AIDS.

Shortly after homosexuality was considered as an at-risk category of AIDS transmission, the Ministry of Health worked with the Police Agency to compile a 
list of male prostitutes and homosexuals to be tracked in the name of AIDS prevention (United News 1985). Against this background, policing homosexuality was not uncommon in the 1990s. ${ }^{1}$ Moreover, the legislation of AIDS Control Act in 1990 had restricted HIV-positive non-nationals' international travel. The Act required non-nationals who planned to stay in Taiwan for more than three months to provide a report of their HIV-negative status before they could be given permission to enter Taiwan. Besides, non-nationals staying in Taiwan were to be deported once they had tested positive for HIV. The creation and endorsement of these administrative and legal regulations arguably were in part based not only on a racial and sexual imagination of regions outside national borders, but also on an imagination of a fortress nation defending itself from an invasive global pandemic.

\section{The Inclusion Project}

A more recent imagination of the global ushered in a new vision of the nation. Since the 2000s, instead of framing AIDS in moral terms that resulted in the policing of homosexuals, the Taiwanese government has subcontracted some HIV prevention services to NGOs that were able to reach the gay ${ }^{2}$ community and provide it with these services at a number of venues, including parks, cafeterias, bars, gyms, and saunas. In so doing, the government aimed at "building relations with the gay community with the assistance of the nongovernmental sector ... avoiding a misunderstanding by the community that the government is attaching a [negative] label to them" (MoHW 2014, 39). The policies which were even more indicative of the shift in state practices included launching a website promoting safer gay sex in 2008 and the manufacturing and distribution of safe-sex products in 2009. Both were funded by the Taiwan Centers for Disease Control (TCDC) ${ }^{3}$ and implemented by NGOs. These programs not only promoted a global, liberal view of gays but also actively produced localized gay cultures, including images, information, knowledge, and material products (MoHW 2014, 38-39). All of a sudden, homosexuality and gay identity were no longer deemed Western, but were given localized expressions.

1 Homosexuality per se has never been criminalized in Taiwan; however, individuals engaging in homosexual acts could be charged with the "violation of moral customs" by the police permitted by laws such as the Social Order Maintenance Act.

2 Since late 1990s and early 2000s, the term “homosexual” (同性戀) has gradually been replaced with the term "gay" (同志) in state and public discourses in Taiwan.

3 Taking the framework of the U.S. CDC as a reference, TCDC was established in 1999 by merging three previous departments and it became the primary governmental agency in charge of HIV prevention work. 
In 2010, TCDC spent 4.8 million New Taiwan Dollars (roughly 160 thousand USD) on establishing two gay health community service centers in two cities, a program that aimed at engaging the gay community in HIV prevention. Due to the perceived difficulty in reaching the community, TCDC subcontracted the program to NGOs working on HIV prevention and care, in an attempt to "offer education and services on HIV prevention to the gay community in a friendly, warm, low-key, and fashionable environment" (MoHW 2014, 39). In 2011, the state budget for the operation of three gay health community service centers (one more established) increased to 7.8 million NTD (roughly 260 thousand USD), which accounted for almost $2 \%$ of the annual state budget for chronic disease prevention and treatment (The Legislative Yuan 2010, 163). By 2014, there were already five of these centers in cities directly funded by TCDC, and other 15 centers all over Taiwan funded by local governments after TCDC made the program into a statewide policy (MoHW 2016, 33).

Not only did the state transform to cooperate with the nongovernmental sector, nationhood was also re-articulated. These new centers went beyond delivering health services as stipulated by the plans formulated by TCDC and local governments, and dedicated themselves to community-building and the promotion of cultural recognition, facilitating a new imagination of the nation. At times when TCDC was accused of stigmatizing the gay community by advocates, it defended itself by highlighting the programs they supported: “The Centers for Disease Control has been actively building gay friendly environments and has established gay health community service centers and a gay health hot line ... It by no means stigmatizes the gay community and AIDS patients” (TCDC 2012). Now, what the state defended was an inclusive nation instead of a moral nation.

What were the global imaginations that undergirded the transformation of the imagination of the nation along the dimensions of sexuality? Given that direct information on the policy-making process of TCDC is not available and that TCDC has meant to keep a low profile in its role in endorsing gay health community service centers, news archives offer little information. Nevertheless, it is still possible to unveil how the articulation of global health with the nation changed by examining policy-related documents and interview data. Back in 2006, TCDC released a press briefing after holding the 8th Taipei International AIDS Conference, inaugurated in 1990 by the Taiwanese government and held biannually since. The press briefing stated:

In this platform for international exchange, experts from different parts of the world were invited to share their experiences on HIV prevention.... In the future, the government should work with NGOs and the gay community to promote educational programs on safer sex; that 
way, [Taiwan’s] HIV prevention work could keep up with international society (與國際接軌) and take further steps towards a new century of epidemic prevention (TCDC 2006).

Here, the increasing HIV prevalence in the gay community was regarded as a localized issue rather than a Western one, and community engagement was considered as a leading solution posed by international (mostly Western) global health experts. The West was no longer a source of the AIDS problem but became a pioneer in fighting AIDS, and sexuality was not merely a problem but also a key to solving the problem.

Such an articulation of a global health approach to sexuality could also be found in a press briefing released by TCDC after holding the 10th Taipei International AIDS Conference in 2010. In the briefing, TCDC expressed its commitment to an inclusive approach to gay sexuality by stating that "learning from their [Japan's and the U.S.'s] intervention strategies for engaging the MSM [men who have sex with men] community would help the government in advancing prevention work" (TCDC 2010a). Moreover, in the only press briefing released by TCDC regarding the establishment of gay health community service centers, dominant global health values for HIV care - such as anti-discrimination, inclusion, diversity, and community engagement - were emphasized as the government's principles of HIV-related policies (TCDC 2010b). Even when HIV prevention programs aiming at engaging the gay community were being questioned by a legislator, the director of TCDC was able to justify its policy by appealing to a global and national imagination simultaneously: "there are many countries working on incorporating NGOs for [HIV prevention] work ... we are learning effective approaches from them" (The Legislative Yuan 2010, 152). While effectiveness is certainly a central consideration in introducing a new policy, my data indicate that the institutional restructuring of the state and the cultural re-articulation of nationhood has just as much to do with the perceived need to "keeping up with international society," and with the fear of isolation from international society (represented by the West). By embodying an inclusive approach to sexuality, the state was able to assert a globally progressive nationhood and an "in-pursuit-of-globality nationalism."

This nationalism was manifested in my interviews with TCDC officers as well. The officers not only confirmed the fact that the inclusive approach to sexuality was informed by the U.S. and Japan, but also proudly shared with me the multiple connections they built with "international society." When I asked how other countries' policies might play a role in Taiwan's policy-making, one officer said:

A lot. We learn from others' policy experiences by studying. We study a lot.... We imported case management policy from the U.S. We learned from Australia to implement harm reduction programs among injecting drug users. We learned from Japan and the U.S. about 
gay health center programs.... We compile national treatment guidelines by referencing guidelines issued by U.S. Department of Health and Human Services, International Antiviral Society-USA, European AIDS Clinical Society, and British HIV Association. We pay close attention to WHO and UNAIDS guidance. We have representatives attending international conferences every year - the International AIDS Conference and the Conference on Retroviruses and Opportunistic Infections are the must-go ones, and we also attend the ones in Europe and those for Asia-Pacific (Interview 15 August 2019).

In fact, one could notice even more from HIV Prevention Programs and other articles published by TCDC officials how "international society" informs state practices - from policy-making to assessment, and from prevention to treatment. Given the amount of effort by TCDC in aligning its work with those of the West, it would be insufficient to understand the building of these multiple transnational connections merely from a technical perspective. Rather, I argue that a nationalism asserted through building transnational connections and achieving an imagined globality (here, represented by an inclusive approach to sexuality) was at work, mediating the ways in which both nationhood and the state were reconfigured.

Likewise, a quotation from another officer demonstrates his proudness in TCDC's ability to sustain international connections and to adopt a global health approach to sexuality:

Taiwan is in a special status and could not participate in international organizations. However, we are not disconnected from the international. Although it is unlikely to access international resources, our government and nongovernmental sector have been self-reliant. While official relationships are not open to us, we are able to build unofficial relationships with the U.S., Japan, and others.... Thus, we are keeping up with global health [experts]; our work has never been outdated.... CDC is a rather flexible and open-minded governmental agency. As vulnerable groups are hit by AIDS, the government should adopt a community approach to combat the epidemic (Interview 6 May 2019).

As is clear from this quote, by flexible and open-minded, the official was referring to the adoption of an inclusive approach to sexuality and the implementation of gay health community service center programs. Such a community-centered approach was not merely a practical manifestation of adopting global health practices, but also a symbolic path to "international society" and to a renewed membership in the global community of nations. In this regard, Taiwan's nationalism was therefore not asserted through the decoupling of the national and the global, but instead through the (re-)articulation of the two. 


\section{The Rights Project}

Before 2015, the HIV Infection Control and Patient Rights Protection Act ${ }^{4}$ denied entry to and mandated the deportation of HIV-positive immigrants. An HIV test was required by law before a non-national could be granted a student, working, or spousal immigration visa. Moreover, annual HIV test was also required for bluecollar migrant workers and some other categories of migrant workers before their immigration visa could be renewed. According to TCDC's statistics, there were almost one thousand immigrants, including workers, students, and spouses, deported by the Taiwanese state between 1990 and 2014 (TCDC 2015). Race was at the center of the moral project of AIDS prevention and of the imagination of the nation.

However, the legal article that restricted HIV-positive non-nationals' immigration was repealed in January 2015. Since then, the immigration application no longer requires a HIV examination, and HIV-positive immigrants no longer need to be deported. On the day when the amendment was passed by legislators, TCDC released a press briefing entitled "HIV Act amendment fights discrimination and recognizes human rights," announcing the amendment and celebrating nationhood with a global language of human rights:

\footnotetext{
International society has viewed HIV as a chronic disease. Unequal treatment of HIV-positive individuals goes against the international human rights trends and limits the efficacy of HIV prevention. To realize equal rights, today the government has passed an amendment to the HIV Infection Control and Patient Rights Protection Act which no longer restricts the entry and stay of HIV-positive non-nationals. The law's amendment signifies not only the connection between our national HIV prevention policy and an international one, but also a new stage in protecting the rights of HIV-positive individuals... The amendment complies with the international principle of human rights and corresponds with the need of HIV prevention... By bridging HIV human rights and treatment in Taiwan with international society, we are heading toward the goal of "Close the Gap" (TCDC 2015).
}

In this script, TCDC repeatedly highlighted human rights as something shared between "international society" and the nation-state, and propagated the theme "Close the Gap," which was the theme of 2014 promoted by UNAIDS (Joint United Nations Programme on HIV/AIDS). TCDC invoked the discourse of human rights specifically to counter the earlier racialized imagination of AIDS and to address the reorganization of the state along the line of race.

The language of rights appeared not only in the script to the public but also in policy documents such as HIV Prevention Programs: "Due to increasing numbers of

4 The AIDS Control Act was renamed as HIV Infection Control and Patient Rights Protection Act in 2007. 
foreign spouses and based on the international principle of human rights, an amendment to the HIV Act was passed in 2015 to protect foreigners' right to freedom of movement ... " (MoHW 2016: 37). Furthermore, when a rumor about an HIV-positive care-giving migrant worker spread in 2016, TCDC issued a press release which on the one hand appeased public anxiety by restating basic HIV knowledge, and on the other reiterated the notion of rights:

HIV-positive migrant workers should not be discriminated against. Employers could not fire migrant workers merely because of HIV status... The CDC is pleased to see employers protecting migrant workers' right to employment.... As a universal value, patients' human rights do not differ according to their nationality (TCDC 2016).

As one can see, state practices with respect to the HIV examination and deportation of immigrants have undergone a significant transformation since the 2015 law amendment. In addition, nationhood was redefined in terms of human rights, understood in the context of anti-racism towards HIV-positive immigrants. The idea of rights and its racial significance has become a terrain on which an "inpursuit-of-globality nationalism" was contended, which entailed another transformation of the state and nationhood.

In what follows, I unpack what I call the rights project and the global and national imagination it produced that has contributed to the shift in the racial configuration of the state and nationhood. Persons with HIV/AIDS Rights Advocacy Association (PRAA) is the NGO in Taiwan that perhaps has been the most active on rights advocacy for HIV-positive immigrants. PRAA has been offering social services to HIV-positive immigrants since 2000, assisting them with legal issues and procedures as well as healthcare. PRAA also made some of its social work with immigrants into public news (with their clients' consents), in an attempt to raise public awareness about situations confronting HIV-positive immigrants. Early in 2000, PRAA held a press conference stating that an immigrant spouse of a Taiwan national was deported by the state due to the spouse's HIV status. PRAA also publicized stories of their clients in its publicly available journal Rights Magazine (權雜誌). In a 2002 volume, a social worker briefly wrote about the predicament of four immigrants and their families (Lin 2002). In volumes of 2003, 2004, and 2005, there were articles elaborating stories of immigrants and the difficulties in going through some official procedures in more depth (Chang 2005; Lin 2003, 2004, 2005; Lisa 2005). In these writings, the ideal of human rights was contrasted with the difficulties HIV-positive immigrants encountered because of the law, and these were narrated with sympathy and compassion.

The narratives, however, have changed since 2009; the idea of rights was linked to an imagination of global health as well as nationhood, in addition to immigrants' difficult livelihood. In a 2009 volume of Rights Magazine, PRAA 
stated, “denying HIV-positive immigrants' entry does not lower the HIV prevalence in Taiwan ... but instead affects our nation's reputation in international society" (PRAA 2009, 6). "International society” emerged in the rights discourse. In 2010, PRAA facilitated the formation of Taiwan Alliance for Migrants Living with HIV/AIDS (TAMLHA) with more than ten other NGOs concerning migrant rights, whose aim was to achieve legal reform. The Alliance's demonstration against the government in 2010 gained new attention in the media and since then, it has been framing the reform in terms of human rights strategically. Their press release stated, "repealing legal restrictions on HIV-positive immigrants is a key way of promoting Taiwan's international profile” (TAMLHA 2010). News articles further publicized their message:

\begin{abstract}
Despite the state's avowal to protect human rights, Taiwan's law which restricts the immigration of HIV-positive foreigners is incompatible with the international idea of human rights protection and with international treaties on human rights. We urge the government to fight discrimination against HIV-positive individuals and to repeal the outdated act. (Central News Agency 2010)
\end{abstract}

According to the UN Commission on Human Rights, restricting the immigration of HIV-positive individuals violates human rights. But the Taiwanese government is still imposing restrictions on HIV-positive immigrants.... China, the U.S., and South Korea have repealed their twenty-year-long immigration restrictions on HIV-positive individuals. Taiwan is one of the fifty regions in the world that still have some sorts of restrictions.... We urge the government to respect the international principle of human rights (Taiwan Shin Sheng Daily 2010).

In these discourses, the notion of rights not only was mobilized to counter a racialized perception of AIDS, but was also viewed as something that represented "international society" and thereby could be leveraged to facilitate reform of the state. Behind the discourse of rights was a particular (anti-racist) imagination of global health and of the nation being part of a larger community of global health.

Such a narrative and global imagination of rights continued to flourish. The Taiwan Lourdes Association, a member of TAMLHA, published an article about the story of an HIV-positive immigrant in its 2011 journal and concluded by stating, "current law deprives them of their right to staying in Taiwan ... we look forward to legal reform that reflects the international principle of rights protection in Taiwan" (TLA 2011). In another article entitled "Is Taiwan behind the trend of HIV human right to movement?," a social worker at PRAA compared the state regulations and policies on immigration and healthcare among Taiwan and other three states - the U.K., Canada, and Italy - and reflected on Taiwan's "backwardness" in these areas (Yeh 2011a, 2011b). The article transformed the abstract “international society" into 
exemplary states, but also turned the intangible, global idea of rights into comparable state regulations and policies.

An imagination of global health became ever more concrete as the rights discourses were connected to global health institutions. In 2011, the Taiwan Association for Human Rights, also a member of TAMLHA, translated and published an article entitled "The global database on HIV-related travel restrictions," in which a number of states of the world were compared and categorized with respect to regulations on immigration, and major international (or multilateral) organizations - UNAIDS, International Organization of Migration, International AIDS Society, the Global Funds, etc. - were cited to advocate for lifting restrictions on HIV-related international movement (Chiu 2011). During the period between 2010 and 2014, activists continued to post domestic news concerning HIV-positive immigrants being deported by the state on TAMLHA's blog and Facebook page, but also reposted and highlighted articles by global health organizations on rights to international travel. For instance, TAMLHA contended in one of its posts:

On January 5, 2010, UNAIDS noted that state restrictions on HIV-positive individuals' entry does not benefit public health and calls for a repeal of those restrictions.... On September 25, 2009, UN Human Rights Council also called for an elimination of HIV-related restrictions on immigration.... We hope that Taiwan does not fall behind the international trend in human rights (Yeh 2011a, 2011b).

Again, the post presented a visible and tangible globality, materialized as state regulations of immigration that follow the global principle of rights, which could be pursued and achieved by the Taiwanese state. In 2012, TCDC responded to these domestic NGOs' call with a press briefing entitled "HIV-positive immigrants are protected," which, however, further engendered discontents from advocates (Yeh 2012).

Nevertheless, AIDS advocates took the opportunity of participating in Taiwan's human rights-related treaty review mechanism to urge the state to amend the Act. The creation of this unique treaty review mechanism has to do with the Taiwanese government's desire for but simultaneous inability to conclude United Nations-based treaty due to Taiwan's status. In order to demonstrate the Taiwanese people's commitment to engaging in international affairs, legislators have passed some UN-based treaties, aiming to align national laws with them. One is the Convention on the Elimination of All Forms of Discrimination Against Women (CEDAW), passed in 2007; another two are the International Covenant on Economic, Social and Cultural Rights (ICESCR) and the International Covenant on Civil and Political Rights (ICCPR), passed in 2009. To implement a treaty review mechanism that operates among the actual member states of the UN that concludes the treaty adoption, the Taiwanese government invited international 
experts of human rights to Taiwan to review national reports written by the government from the perspective of those treaties. Domestic NGOs focusing on human rights were included in the review process; they wrote parallel reports which were to be considered by international experts in parallel with national reports and participated in meetings with those experts. AIDS advocates were also invited to compile grievances in those parallel reports. ${ }^{5}$

In Parallel Reports on the Implementation of the International Covenant on Civil and Political Rights written for the international review in 2013, immigrant cases affected by the HIV Prevention Control and Patient Rights Protection Act were presented, and how state regulations restricting the stay and movement of HIV-positive immigrants could contradict with ICCPR was discussed (Covenants Watch 2012, 109-10, 126-28). Similarly, another parallel report on CEDAW written for the 2014 review elaborated the ways in which the rights of HIV-positive women migrants could be violated by national law (Yeh 2013). As the international review committees took up these issues reported on by NGOs, the Taiwanese government responded, "we are working to repeal the restrictions on the immigration of HIV-positive non-nationals” (GoT 2013, 125). In October 2013, news reported, “Taiwan's current regulations are not in line with UNAIDS's suggestion ... A draft of the amendment of the law will soon be submitted to the Ministry of Health and then the Legislative Yuan" (Central News Agency 2013). As such, a human rights approach to HIV-positive immigrants was institutionalized by the Taiwanese state in order to counter the racialized perception of the AIDS epidemic and it became a framework for the state's positioning itself vis-à-vis "international society."

\section{Imagining Globalities From Below}

In this article, I have demonstrated a way of reconceptualizing global health from a global ethnography perspective which emphasizes a grounded imagination of the global. I argue that, in Taiwan's case, global health and the supra- and transnational scales are neither monolithic nor static; instead they are contested imaginations which are invested and produced by situated actors involved in various kinds of cultural, political and social projects. This has implications for global health research and global studies by transcending the traditional hierarchical view of scales where the power relations between the global and the local

5 An explanation of the treaty reviewed process and the reports written for the reviews could be found on the webpage of Covenants Watch, a Taiwan-based NGO promoting human rights https:// en.covenantswatch.org.tw/\#. 
are predetermined (Brenner 1999; Sassen 1995, 2005), and by recognizing the plurality of the global at play.

This article also incorporates and contributes to a transnational perspective on gender, race, and sexuality by underscoring that the making and remaking of the global and the national are inflected by race, gender, and sexual orientation. By contrasting three projects in Taiwan responding to the AIDS pandemic, it discloses how the shifting racial, sexual, and gendered configurations of the nation-state were fashioned by competing global imaginations. In the moral project, AIDS was viewed as something associated with deviant sexuality, gender, and race outside the nation. Such a construction of the global as a threat to the nation justified the imagination of the nation as asserting racial, gendered, and sexual moral superiority. In the inclusion project, the global - the West, in particular - was imagined by the state as the solution to rather than a source of the problem of AIDS. An inclusive approach to sexuality proposed by Western countries was adopted not only to reorganize state practices towards the gay community but also to redefine nationhood in terms of diversity and inclusion. In the rights project, the West qua global was constructed strategically by civil society organizations as a role model of human rights fighting against racism which the Taiwanese state should emulate. As a result, state regulations and practices, again, were refashioned and the idea of rights became central in the re-articulation of nationhood.

The co-constitution of the global and the nation-state, I argue, should be understood in the context of Taiwan's marginal status in the international community. This study unveils the "in-pursuit-of-globality nationalism" derived from Taiwan's marginality and contends that the transformations of the state and nationhood in global imaginations - particularly those of the inclusion project and the rights project - only make sense when a collective mentality of fear of disconnection, if not isolation, from an imagined international society is at work (Tsing 1994). As Ferguson (2002) has pointed out, globalization creates connection but also disconnection and abjection. Taiwan offers another case for global studies scholars to consider how a positionality of disconnection also calls forth competing imaginations of the global and the contestation of dominant views of the global and the national.

Acknowledgment: I thank Zsuzsa Gille for her generous comments on this article, which benefitted from my conversations with Shun-Nan Chiang, Wen-Ling Kung, Yen-Chiao Liao, Ho-Ching Jiang, and Meng-Che Tsai. I thank the editors for their constructive feedback. I also gratefully acknowledge funding for the research on which the article is based: the Department of Sociology and the Graduate College at the University of Illinois at Urbana-Champaign, and Chiang Ching-kuo Foundation for International Scholarly Exchange. 


\section{References}

Biehl, J. 2004. “The Activist State." Social Text 22 (3): 105-32.

Biehl, J. 2007. Will to Live: AIDS Therapies and the Politics of Survival. Princeton: Princeton University Press.

Brenner, N. 1999. "Beyond State-Centrism? Space, Territoriality, and Geographical Scale in Globalization Studies." Theory and Society 28: 39-78.

Brown, H. 2015. "Global Health Partnerships, Governance, and Sovereign Responsibility in Western Kenya." American Ethnologist 42 (2): 340-55.

Burawoy, M. 2000. "Introduction: Reaching for the Global." In Global Ethnography: Forces, Connections and Imaginations in a Postmodern World, edited by M. Burawoy, J. A. Blum, S. George, Z. Gille, T. Gowen, L. Haney, M. Klawiter, S. H. Lopez, S. Ó. Riain, and M. Thayer, 1-40. University of California Press.

Cassidy, R., and M. Leach. 2010. "Mediated Health Citizenships: Living with HIV and Engaging with the Global Fund in the Gambia." In Globalizing Citizens: New Dynamics of Inclusion and Exclusion, edited by J. Gaventa, and R. Tandon, 33-55. London: Zed Books.

Central News Agency. 2010. Legal Restrictions on HIV-Positive Foreigner's Travel. Central News Agency. 7 November.

Central News Agency. 2013. Ministry of Health and Welfare Attempts to Amend the Law So that No More Deportation of HIV-Positive Foreigners. Central News Agency. 18 October.

Chang, J.-L. 2005. “A Brave and Strong Mother.” Rights Magazine 17: 33-5.

Chiu, E.-L. 2011. "Movement: A Basic Human Right of HIV-Positive People.” Taiwan Association for Human Rights PAS (Summer): 3-9. (edited translation of the article "The Global Database on HIV Related Travel Restriction" from www.hivtravel.org.

Chua, L. J., and T. Hildebrandt. 2014. "From Health Crisis to Rights Advocacy? HIV/AIDS and Gay Activism in China and Singapore." Voluntas: International Journal of Voluntary and Nonprofit Organizations 6: 1583.

Covenants Watch. 2012. Parallel Reports on the Implementation of the International Covenant on Civil and Political Rights. Covenants Watch. https://covenantswatch.org.tw/wp-content/ uploads/2018/12/2013-ICCPR-State-Reports-Shadow-Report_EN.pdf.

Decoteau, C. L. 2013. "Exclusionary Inclusion and the Normalization of Biomedical Culture." American Journal of Cultural Sociology 1 (3): 403-30.

de la Dehesa, R. 2017. "NGOs, Governmentality, and the Brazilian Response to AIDS: A Multistranded Genealogy of the Current Crisis.” Feminist Studies 43 (2): 262-90.

Esacove, A. 2016. Modernizing Sexuality: U.S. HIV-Prevention Policy in Sub-Saharan Africa. New York: Oxford University Press.

Fassin, D. 2007. When Bodies Remember: Experiences and Politics of AIDS in South Africa. Berkeley: University of California Press.

Follér, M.-L. 2010. “Civil Society Organizations and Brazilian South-South AIDS Cooperation.” The Global South 4 (1): 199-218.

Gideon, J., and F. Porter. 2016. "Challenging Gendered Inequalities in Global Health: Dilemmas for NGOs." Development and Change 47 (4): 782-97.

Gille, Z., and S. Ó. Riain. 2002. "Global Ethnography.” Annual Review of Sociology 23: 271-95. Government of Republic of China (Taiwan). 2013. Replies of Republic of China (Taiwan) to the List of Issues. Also available at https://covenantswatch.org.tw/wp-content/uploads/2018/12/ 2013-ICCPR-Replies-to-LOIs_Bilingual.pdf. 
Harman, S. 2009. "Fighting HIV and AIDS: Reconfiguring the State?." Review of African Political Economy 36 (121): 353-67.

Hartwig, K. A., E. Eng, M. Daniel, T. Ricketts, and S. C. Quinne. 2005. "AIDS and "Shared Sovereignty" in Tanzania from 1987 to 2000: A Case Study." Social Science \& Medicine 60 (7): 1613-24.

Ho, C.-H., and L. Peng. 1988. AIDS and Prevention Methods. Hong Kong: Nanyue Press.

Hood, J. 2012. "HIV/AIDS and Shifting Urban China's Socio-Moral Landscape: Engendering BioActivism and Resistance through Stories of Suffering." International Journal of Asia Pacific Studies 8 (1): 125-44.

Howard-Payne, L., and B. Bowman. 2018. "Citizenship in a Time of HIV: Understanding Medical Adult Male Circumcision in South Africa." Journal of Health Psychology 23 (6): 871-81.

Jönsson, C., and K. Jönsson. 2012. "Global and Local Health Governance: Civil Society, Human Rights and HIV/AIDS.” Third World Quarterly 33 (9): 1719-34.

Kaufman, J. 2012. “China’s Evolving AIDS Policy: The Influence of Global Norms and Transnational Non-Governmental Organizations.” Contemporary Politics 18 (2): 225-38.

Kim-Puri, H. J. 2005. “Conceptualizing Gender-Sexuality-State-Nation: An Introduction.” Gender \& Society 19 (2): 137-59.

Ko, S.-L. 1988. Challenging AIDS. Taipei: Kuochia Press.

Knutsson, B. 2014. "Smooth Machinery: Global Governmentality and Civil Society HIV/AIDS Work in Rwanda." Globalizations 11 (6): 793-807.

Lin, Y.-H. 2002. "People Who Do Not Live in the Global Village." Rights Magazine 13: 55-6.

Lin, Y.-H. 2003. “A Report on Foreign Nationals in Taiwan.” Rights Magazine 14: 31-2.

Lin, Y.-H. 2004. "A Door of Hope for Lisa." Rights Magazine 15: 36-7.

Lin, Y.-H. 2005. “There is Hope if We Don't Give Up.” Rights Magazine 17: 30.

Lisa (dictation). 2005. "A Chinese Wife in Taiwan." Rights Magazine 17: 30-2.

Long, Y. 2018. "The Contradictory Impact of Transnational AIDS Institutions on State Repression in China, 1989-2013.” American Journal of Sociology 124 (2): 309-66.

Min Sheng Daily. 1991. "An Open Letter to the Nation on the Fight against AIDS." Min Sheng Daily. 5 November.

Ministry of Health and Welfare. 2014. Five-Year HIV Prevention Programs (Phase 5) (revision). May. Ministry of Health and Welfare. 2016. Five-Year HIV Prevention Programs (Phase 6). July.

Nguyen, V.-K. 2005. “Antiretroviral Globalism, Biopolitics, and Therapeutic Citizenship.” In Global Assemblages: Technology, Politics and Ethics as Anthropological Problems, edited by A. Ong, and S. Collier, 124-43. Malden, MA: Blackwell.

Persons with HIV/AIDS Rights Advocacy Association. 2009. Rights Magazine 20.

Persson, A. 2016. “'The World Has Changed': Pharmaceutical Citizenship and the Reimagining of Serodiscordant Sexuality Among Couples with Mixed HIV Status in Australia." Sociology of Health and Illness 38 (3): 380-95.

Powers, T. 2016. "HIV/AIDS Policy, Transnational Donor Capital, and Localized Political Formations in South Africa." Human Organization 75 (3): 239-48.

Robins, S. 2004. “'Long Live Zackie, Long Live': AIDS Activism, Science and Citizenship after Apartheid." Journal of Southern African Studies 3: 651.

Sassen, S. 1995. "The State and the Global City: Notes towards a Conception of Place-Centered Governance." Competition and Change 1: 31-50.

Sassen, S. 2005. "The Global City: Introducing the Concept." Brown Journal of World Affairs (Winter-Spring): 27-43. 
Swidler, A., and S. C. Watkins. 2017. A Fraught Embrace: The Romance and Reality of AIDS Altruism in Africa. Princeton: Princeton University Press.

Taiwan Alliance for Migrants Living with HIV/AIDS. 2010. "A Call on the Taiwanese Government to Repeal the Restrictions on HIV-Positive Foreigners." 7 November.

Taiwan Centers for Disease Control. 2006. "The 8th Taipei International AIDS Conference on MSM (Men Who Have Sex with Men) and HIV Prevention Raises Public Awareness of the AIDS Problem." 10 September.

Taiwan Centers for Disease Control. 2010a. "HIV Infection among Men Who Have Sex with Men Should Not Be Neglected.” 24 September.

Taiwan Centers for Disease Control. 2010b. "Gay Health Centers Established to Build a Healthy and Friendly Environment.” 27 February.

Taiwan Centers for Disease Control. 2012. “CDC's Response to Mr. Jiang Ho-Ching's Article "Regulation Does Not Stop the Spread of AIDS" on the Stigmatization of Gay Men and HIV in Current HIV Prevention Work." 26 July.

Taiwan Centers for Disease Control. 2015. "HIV Act Amendment Fights Discrimination and Recognizes Human Rights.” 20 January.

Taiwan Centers for Disease Control. 2016. "HIV Will Not be Transmitted through Common Daily Behaviors. We Care about HIV Regardless of One's Nationality. Do Not See Them as Strangers." 15 July.

Taiwan Lourdes Association. 2011. A Long Way to Home Because of HIV. Taiwan Lourdes Association Annual Report 25.

Taiwan Shin Sheng Daily. 2010. "NGOs Urge to Lift Restrictions on HIV-Positive Foreigners." Taiwan Shin Sheng Daily. 8 November.

The Legislative Yuan. 2010. The Legislative Yuan Gazette, 99 (79).

Thörn, H. 2016. "Politics of Responsibility: Governing Distant Populations through Civil Society in Mozambique, Rwanda and South Africa.” Third World Quarterly 37 (8): 1505-23.

Tsing, A. L. 1994. "From the Margins." Cultural Anthropology 9 (3): 279-97.

Twu, S.-J. 1995. Global AIDS Prevention Manual. Taipei: Hsinglin Culture.

United News. 1985. "Suspected Deadly AIDS Patient Found in the Nation." United News. 30 August. United News. 1987a. "AIDS Flourishes in New York, Two Died in China Town." United News. 10 January.

United News. 1987b. “Asia Will Become a New Battlefield as AIDS Searches for a Fall Guy.” United News. 23 February.

United News. 1987c. Asia Is in Trouble as AIDS Spreads. United News. 26 June.

United News. 1987d. Do Not Sleep Around with Wild Flowers in the Philippines as AIDS is Coming. United News. 26 May.

Yeh, C.-C. 1993. What to Know about AIDS. Taipei: International Village Bookstore.

Yeh, C.-Y. 2011a. "The Implication of Repealing Travel Restrictions on HIV-Positive Foreigners for HIV Prevention.” Available at: https://praatw.org/news/649 (accessed September 1, 2020).

Yeh, C.-Y. 2011b. "Is Taiwan Behind the Trend in HIV Human Right to Movement?." Rights Magazine 11: 4-5.

Yeh, C.-Y. 2012. “A Response to CDC's Release “HIV-Positive Immigrants Are Protected.” Available at: https://praatw.org/news/639 (accessed September 1, 2020).

Yeh, C.-Y. 2013. "Women and HIV." In Parallel Reports on the Implementation of CEDAW, Covenant Watch.

Wu, T.-K., ed. (1990). Getting to Know about AIDS. Taipei: Women Children Family Press. 